infection if they don't refrain from having sex until the wounds have fully healed and that women may find it more difficult to insist on condom use with circumcised men.

Given these concerns, the CNS calls for implementation schemes to be accompanied by public education as well as research that considers the behavioural and cultural factors that affect HIV transmission. Such research is already under

"The impact of circumcision on way at various sites. At Orange Farm, a 5-year follow-up study of 30,000 people will look at how the implementation of a real circumcision campaign affects risk behaviours, and HIV prevalence will depend on a host of social and cultural factors." overall HIV prevalence in the population.

Tim Farley, an official in the WHO's HIV prevention team in Geneva, says he "absolutely agrees" with the CNS view, and the need for such research. "These are concerns that need to be studied, but they are not a reason to stop," he says. "We must move ahead in the knowledge that there could be riskier behaviour." Declan Butler and Lucy Odling-Smee

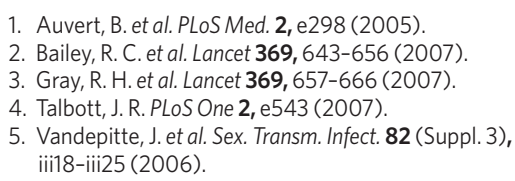

and significance will be further ascertained by online comments and discussion by other scientists that are posted on PloS One's website after publication.

"The paper is total drivel, it should have been picked up in the review process," claims Tim Farley, an official in the World Health Organization's HIV-prevention team in Geneva. "And coming from PLoS One gives [the views in the press release] a public perception of validity. In public health there are severe dangers in such stuff getting through."

"There are lessons to be learned from all papers that we publish; we are a young journal," says Chris Surridge, PLoS One's managing editor, adding that its peer-review model is constantly under refinement. "We are feeling our way."

In this case, the paper was reviewed by a member of PloS One's editorial board and one external referee. The review criteria of PLOS One are that "the data are sufficient to be published and the conclusions not radically overstated by the data," Surridge explains. "I hope we get some discussion of this paper [in the online post-publication comments]." D.B. and L.O.-S.
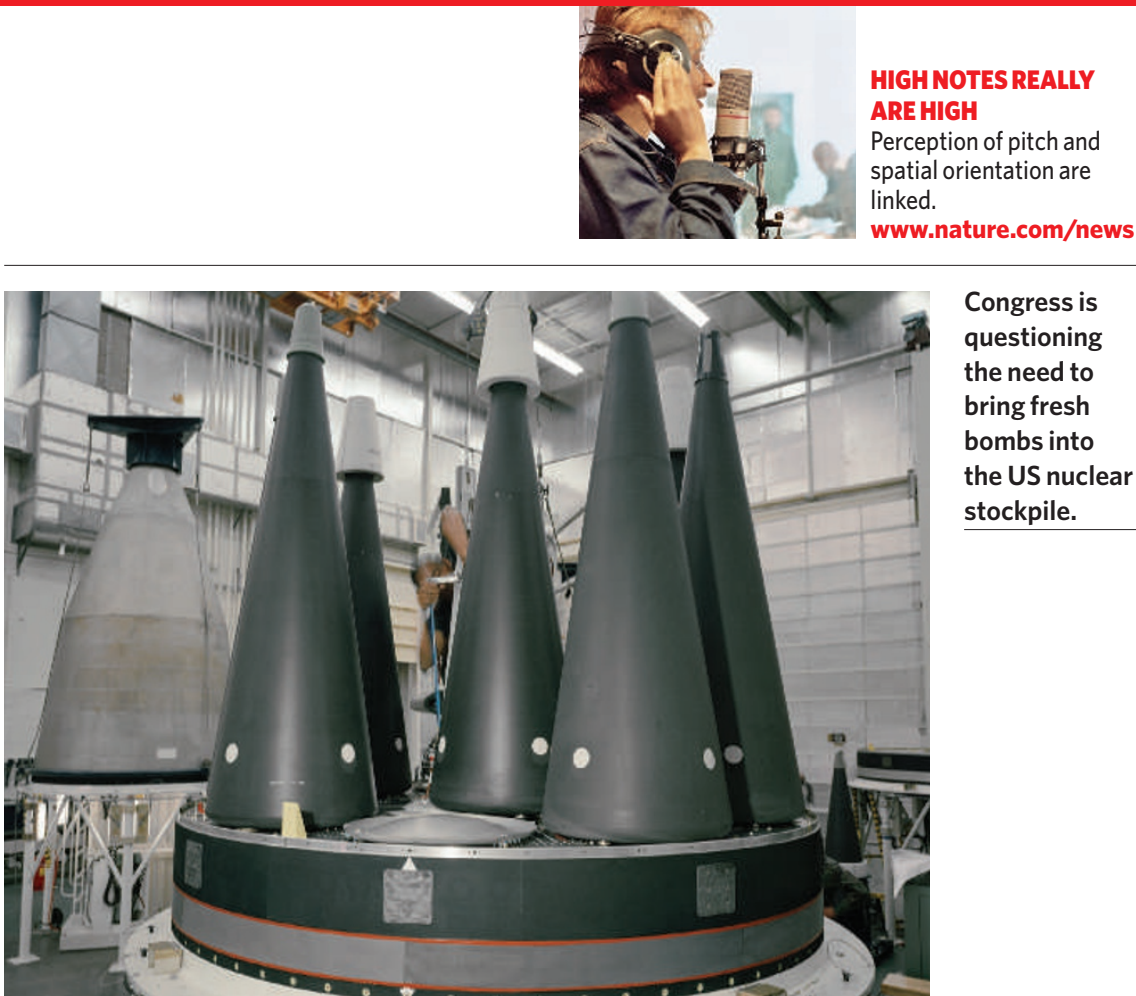

Congress is questioning the need to bring fresh bombs into the US nuclear stockpile.

\title{
Plan for bomb design falters
}

Congress is losing its appetite for the Reliable Replacement Warhead (RRW), a nuclear bomb conceived as a way to allow weapons physicists to ply their trade in a weaponsban world. Instead, Capitol Hill is calling for a full review of the US nuclear programme.

After its 4 July recess, the House of Representatives will vote on a bill that would eliminate funding for the RRW from the 2008 budget. The Bush administration had requested $\$ 89$ million for the project. And committees in both the House and the Senate are drafting legislation that would limit work on the new design to feasibility and cost assessments. That legislation would also call for a review of the need for nuclear weapons.

Until last autumn, the RRW programme enjoyed bipartisan, if tentative, support in Congress. The project, which aims to design a weapon more robust than its predecessors but that requires no testing (see Nature 442, 18-21; 2006), was seen by congressional appropriators as a way to cut the cost of maintaining the nuclear stockpile. Some also liked the idea that it could reduce the size of the stockpile.
But a costly plan released in December on the future of the nuclear weapons complex suggested it would be hard to realize any savings from the RRW. And a study showing that existing warheads will last for at least another 50 years (see Nature 444, 660-661; 2006) made the new bomb seem less necessary. Billions have been spent on 'stockpile stewardship' to prolong the lives of current warheads, Congressman Pete Visclosky (Democrat, Indiana) said on 19 June. Now, he said, "We are told: 'Let's do something else'."

"I don't think it is asking too much for a comprehensive nuclear strategy before we build a new nuclear weapon," added Visclosky, who chairs the subcommittee that withdrew the RRW funding.

A separate defence bill working its way through Congress might provide such a strategy. Versions of the authorization bill, which would set out policy but not funding, call for a comprehensive review of US nuclear policy. This would assess whether the size of the stockpile is appropriate in the post-cold-war era and whether an RRW would be necessary for a credible deterrent.
Arms-control advocates are elated by the move. "What Congress has done is really stunning," says Philip Coyle, a senior adviser at the Center for Defense Information, a think-tank in Washington DC. The current US stockpile is far too bloated, he adds.

But supporters of the RRW say that Congress has undercut the weapons programme. Expertise will be lost unless a new generation can design weapons, says Paul Robinson, former director of Sandia National Laboratories in Albuquerque, New Mexico. He notes that the House budget for nuclear weapons is also $\$ 400$ million lower than that enacted for 2007. "I feel absolutely sure that members of Congress have not looked at the strategic consequences of what they are doing," he says.

The RRW is not done yet. This week, the Senate begins drafting its own version of the appropriations bill. Senator Pete Domenici (Republican, New Mexico) has vowed to win back support for the programme. A final version of the bill, to be worked out between the House and Senate, is expected sometime in the autumn. Geoff Brumfiel 